PRZEGLĄD NAUK HISTORYCZNYCH 2019, R. XVIII, NR 2

http://dx.doi.org/10.18778/1644-857X.18.02.08

C $|\mathbf{P}| \mathbf{E}$

JM13714

Piotr TAFIŁOWSKI

UNIWERSYTET WARSZAWSKI*

(iD https://orcid.org/0000-0003-2798-3249

\title{
Absolutyzm i legitymizacja władzy w Mediolanie pod rządami Ludovica Sforzy „Il Moro”
}

Streszczenie. W tekście podjęto próbę zaprezentowania form legitymizacji władzy, a także środków i narzędzi, jakie wykorzystywał w tym celu uzurpujący sobie władzę nad Mediolanem Ludovico Sforza. Ważnym i ciekawym zagadnieniem są podejmowane przez renesansowych i wczesnonowożytnych władców próby zalegitymizowania nieprawnie zobytej władzy nie tylko środkami politycznymi, lecz także poprzez mecenat kulturalny i artystyczny. Pierwsza część tekstu poświęcona została drodze Ludovica do przejęcia władzy nad księstwem, druga zaś podejmowanym przez niego zabiegom, które miały mu pozwolić ją uprawomocnić.

Słowa kluczowe: Mediolan, Sforzowie, legitymizacja, sztuka, historiografia.

W

roku 1450, po ponad dwu latach zamieszek i chaosu, które nastąpiły po śmierci ostatniego księcia Mediolanu $z$ rodu Viscontich, Filippa Marii, do miasta na czele swych oddziałów wkroczył, witany entuzjastycznie, kondotier Francesco Sforza, mąż Bianki Marii Visconti, nieprawej córki i jedynej spadkobierczyni księcia Filippa Marii Viscontiego ${ }^{1}$. Jego ambicje sięgały o wiele dalej niż tylko dowodzenie oddziałami najemnych żołnierzy. Witany jak wybawca przez ludność miasta wykorzystał szansę, jaka dał mu los i zwieńczył dzieło swego życia, obejmując władzę w jednym z największych i najbogatszych państw włoskich

*Wydział Dziennikarstwa, Informacji i Bibliologii, e-mail: p.tafilowski@uw.edu.pl

${ }^{1}$ Tu i dalej część informacji na podstawie: C.M. Ady, A History of Milan under the Sforza, London 1907, passim. 
oraz zakładając dynastię, która rządziła Mediolanem łącznie przez 85 lat, $z$ czego jednak tylko przez pół wieku w roli suwerennych władców.

Synem i następca Francesca był Galeazzo Maria, który jednak, ginac w 1476 r. w stosunkowo młodym wieku (żył niecałe 33 lata) $z$ rak trzech młodszych spiskowców, nie zdołał zapewnić bezpiecznej sukcesji swoim potomkom. Warto zaznaczyć, że został zabity w imię uwolnienia miasta od tyranii i przywrócenia wolności republikańskich. Tytuł i władza przypadły pierworodnemu Gian Galeazzowi, chłopcu wówczas siedmioletniemu (1469-1494), słabego zdrowia i umysłu. Jego matka, żona Galeazza Marii, Bona Sabaudzka, nie miała zdolności władcy z prawdziwego zdarzenia. Mówi się o niej jako o kobiecie o dość ograniczonych zdolnościach intelektualnych, niepotrafiącej zaskarbić sobie sympatii poddanych i prowadzącej lekkomyślny i rozwiązły styl życia. Po śmierci Galeazza Marii wyszło na jaw, że była kochanką służącego swego męża, Antonia Tazina, co wzbudziło powszechny niesmak. Co gorsza, miała także innych kochanków spośród ludzi niższego stanu. Książe prawdopodobnie wiedział o rozwiązłości żony, choć w gruncie rzeczy niewiele go to obchodziło, a nawet było mu na rękę, jako że ułatwiało mu folgowanie własnym żądzom ${ }^{2}$. W ostatnich latach jego życia (1472-1475) praktycznie nastapił trwały rozkład pożycia małżeńskiego ${ }^{3}$. Same w sobie te plotki obyczajowe nie sa ważne dla naszych rozważań, jednakże musimy je uwzględnić, ponieważ po śmierci księcia dały one przebywającemu dotychczas na wygnaniu w Genui jego 25-letniemu (urodził się 19 sierpnia 1451 r.) bratu Ludovicowi znakomity pretekst do objęcia kurateli nad bratankiem. Kolejnymi krokami było stopniowe przejmowanie kontroli nad mediolańskimi twierdzami, armia, skarbcem oraz aparatem państwowym. Dzięki temu pełzającemu zamachowi stanu Ludovico po pewnym czasie mógł rządzić już nie tylko jako regent de iure, lecz jako de facto władca księstwa.

Wcześniej jednak, w 1471 r., kiedy syn Galeazza Marii Sforzy miał dwa lata, ojciec, działając w porozumieniu $z$ królem Neapolu Ferdynandem I, postanowił zaręczyć go z roczną wówczas Izabelą d'Aragona, córką dziedzicznego księcia Kalabrii i późniejszego króla Neapolu Alfonsa II i własnej siostry Ippolity Sforzy. Z uwa-

2 Por. M. Azzolini, The Duke and the Stars. Astrology and Politics in Renaissance Milan, Cambridge-London 2013, s. 100-101.

${ }^{3}$ A. Perria, Okrutni Sforzowie, Warszawa 1985, s. 80-81, 124. 
gi na bliskie pokrewieństwo obojga nupturientów konieczne było uzyskanie papieskiej dyspensy. Kontrakt ślubny został sporządzony 26 września $1472 \mathrm{r} .^{4}$ (nota bene małżeństwo to doczekało się czwórki potomstwa, a jedna $z$ ich córek, Bona, została żoną króla polskiego Zygmunta Starego) ${ }^{5}$.

Ludovicowi udało się przekonać neapolitańskiego monarchę, aby pomógł mu uzyskać kontrolę nad Mediolanem, odgrywającym kluczową rolę w układzie sił w Italii. „Oczywiście il Moro dał Ferdynandowi do zrozumienia, że będzie działał w interesie pokoju $i$ - zgodnie $z$ prawem - na rzecz swego bratanka, Gian Galeazza, narzeczonego Izabeli, córki pierworodnego syna monarchy". Wkrótce udało mu się całkowicie podporządkować sobie chłopca.

Jednym $z$ tragicznych następstw bezwzględnego dążenia Ludovica do władzy były jego zabiegi o interwencję francuska na terenie Italii. Już wkrótce po zawarciu porozumienia $z$ Ferdynandem I dokonał wolty i rozpoczał dażenia do rozprawy $z$ dotychczasowym sprzymierzeńcem, Neapolem, mającej się dokonać rękami Francuzów. Na zwrocie tym zaważyły niekorzystne dla niego, a fatalne dla małego Gian Galeazza (zmarł po rozpoczęciu inwazji; jak przypuszczano, został przez stryja otruty) wspomniane koligacje. Moro miał powody, by obawiać się interwencji zbrojnej Neapolu na rzecz odsuwanego Gian Galeazza, dlatego też, kiedy zdał sobie sprawę $z$ dokonującego się zbliżenia neapolitańsko-florenckiego i aby zneutralizować jego potencjalnie negatywne skutki, dążył do zawarcia sojuszu między Mediolanem a papieżem Aleksandrem VI (któremu Aragonowie byli niechętni), Wenecją, królem Francji, dworami d'Estów i Gonzagów (1493) ${ }^{7}$.

W kombinacjach tych pojawił się Aleksander VI, ponieważ w czasie konklawe w roku 1492 do obrania na papieża Rodryga Borgii przyczynił się kardynał Ascanio Sforza ${ }^{8}$, brat Ludovica. Rodrygo zobowiązał się popierać politykę Sforzów przeciwko neapolitańskim Aragonom, Ascanio zaś za swe starania otrzymał fortecę w Nepi,

${ }^{4}$ Ibidem, s. 126.

${ }^{5} \mathrm{Na}$ temat planowanych małżeństw Sforzów, których jednym z celów była legitymizacja ich władzy (a także o roli, jaka odgrywali w tym procesie astrologowie), por. M. Azzolini, op. cit., s. 89-98.

${ }^{6}$ A. Perria, op. cit., s. 128.

7 Formalnie było to przymierze obronne, w rzeczywistości chodziło jednak przede wszystkim o zabezpieczenie władzy Ludovica.

${ }^{8}$ M. Pellegrini, Ascanio Maria Sforza: La parabola politica di un cardinale-principe del rinascimento, t. I-II, Roma 2002. 
w okolicach Viterbo, funkcję wicekanclerza Kościoła oraz do dyspozycji wspaniały pałac Borgiów w Rzymie ${ }^{9}$. Oba rody zostały wkrótce skoligacone. Na dłuższą metę jednak wybór ten okazał się nietrafny, zarówno dla Kościoła powszechnego, jak i dla samych Sforzów.

Już pod koniec maja 1493 r. Moro zdał sobie sprawę $z$ tego, że w swych planach $\mathrm{w}$ istocie liczyć może tylko na księcia Ercole d'Este, którego córka, Beatrycze, była jego żona. Aleksander VI formalnie okazywał Ludovicowi życzliwość, $z$ pewnością jednak nie zamierzał wszczynać wojny przeciwko Ferdynandowi. $Z$ tego powodu stopniowo dochodziło do ochłodzenia, a ostatecznie zerwania stosunków między Sforzami a papiestwem. Ascanio popadł w niełaskę, był odsuwany od osoby papieża, aż wreszcie musiał opuścić Stolicę Apostolską. Wenecjanie, mimo zapewnień o przyjaźni, nie dopuszczali możliwości objęcia władzy przez Ludovica. Na początku 1494 r. Sforzy zaczęło zagrażać niebezpieczeństwo także ze strony panujących w Mantui związanych $z$ Wenecja Gonzagów. Na Florencję nie mógł liczyć.

W związku z tym Ludovico podjął starania, by znaleźć nowego sojusznika, który byłby w stanie zapewnić mu trwała protekcję. Jako że wewnątrz Italii nie miał już zaufania do nikogo, w grę wchodziły jedynie siły zewnętrzne. Dlatego też Ludovico zaczął na różne sposoby zachęcać króla Francji do ataku na Neapol ${ }^{10}$. Karol VIII namowy te przyjął chętnym uchem, dzięki czemu w krótkim czasie zawarli oni układ skierowany przeciwko władcy neapolitańskiemu, Ferdynandowi. Wartość tego traktatu była dla Karola niewielka, gdyż książę Moro już w roku następnym przystąpił do antyfrancuskiej Ligi, wraz z cesarzem Maksymilianem (dzięki małżeństwu tegoż $z$ bratanicą Ludovica, Bianką Marią, nastąpiło zbliżenie rodziny Sforzów $z$ cesarstwem) i $z$ Wenecją. Niemniej była to decyzja o doniosłych konsekwencjach, „której niebezpieczeństwa [Ludovico - P.T.] nie potrafił na razie dostrzec. Najazd francuskiego monarchy miał wprawdzie zniszczyć Aragonów, lecz pociagnął za sobą również upadek imponującego dzieła wzniesionego w latach 1450-1466 przez Francesca Sforzę"11.

${ }^{9}$ Który nie miał być prywatna własnościa Ascania, lecz przekazany został przez Aleksandra VI do skarbca papieskiego i służył za siedzibę kancelarii papieskiej. Por. Material for a History of Pope Alexander VI, his Relatives, and his Time, ed. P. De Roo, vol. II (Roderic de Borgia from the Cradle to the Throne), Bruges 1924, s. 356.

${ }^{10}$ F. Guiccardini, The History of Italy, Princeton 1984, s. 21.

${ }^{11}$ A. Perria, op. cit., s. 170. 
Tymczasem Izabela d'Aragona, wówczas już prawie 25-letnia żona Gian Galeazza, młoda kobieta nieustraszonego ducha, alarmowała ojca i dziada, że jeśli nawet nie byli w stanie wywrzeć zemsty za hańbę i poniżenie, jakie cierpiała ona wraz z mężem po odebraniu im należnej władzy i zaszczytów oraz faktycznym zesłaniu do twierdzy w Pawii ${ }^{12}$, to przynajmniej powinni przedsięwziąć jakieś kroki, by zapobiec niebezpieczeństwu, na jakie narażone było życie ich samych, a także ich dzieci ${ }^{13}$. Gry Ludovica nie pozostawały zatem całkowicie niezauważone, nikt jednak nie potrafił się im przeciwstawić.

Marsz armii francuskiej na południe Półwyspu po sforsowaniu Alp rozpoczał się w październiku $1494 \mathrm{r}$. Niemal bez oporu poddały jej się Sabaudia, Saluzzo i Monferrato, po czym dotarła ona do Pawii. W tutejszym zamku, który Ludovico wyznaczył młodym małżonkom na siedzibę, Karol złożył przyjacielską wizytę swemu kuzynowi Gian Galeazzowi, który w tym momencie był już poważnie chory. Dla współczesnych, a także dla częśsi późniejszych badaczy nie ulegało wattpliwości, że padł on ofiarą trucizny (choć żadnych na to dowodów nie udało się jak dotychczas odnaleźć) i że dni życia młodzieńca sa policzone. Inwazja obcych wojsk pozwoliła Ludovicowi na podjęcie bardziej bezwzględnych, niemniej dobrze przemyślanych i starannie zaplanowanych kroków.

Według Guicciardiniego il Moro już w roku poprzednim, zachęcając Karola VIII do najazdu, myślał o tym, że inwazja da mu znakomita okazje do zamordowania Gian Galeazza. Zakładał on, że $\mathrm{w}$ momencie, gdy potężna obca armia znajdzie się w granicach księstwa, nikt nie będzie miał odwagi sprzeciwić się jego postępowaniu czy choćby wyrazić wprost jakiekolwiek obiekcje. I tak rzeczywiście się stało. Choć powszechnie szeptano, że za pomoca trucizny pozbył się swego młodego bratanka, bez problemów uzyskał dla siebie na kilka lat pełnię władzy w księstwie. Dodatkowo pikanterii sprawie przydaje fakt, że Ludovico - sprzymierzony przecież z Walezjuszem - w tajemnicy nalegał, by tytuł i pieczęć księcia Mediolanu zostały mu nadane na mocy inwestytury przez króla rzymskiego, cesarza i zarazem jego powinowatego - Maksymiliana Habsburga. Jakby tego było mało, Ludovico wystapił o nadanie mu inwestytury księstwa na krótko przed śmiercią siostrzeńca ${ }^{14}$. Tak

12 E.S. W e1ch, Galeazzo Maria Sforza and the Castello di Pavia, 1469, „The Art Bulletin" 1989, vol. LXXI, No. 3, s. 352-375.

${ }^{13}$ F. Guiccardini, op. cit., s. 18.

${ }^{14}$ Ibidem, s. 54-55. 
też się stało. Cesarski dyplom, zatwierdzający dla Ludovica wszystkie dostojeństwa i przywileje, jakie od cesarza Wacława otrzymał w roku 1395 Gian Galeazzo Visconti, nosił datę 5 września 1494 r. W preambule podano także powody, dla których pominięto prawa bratanka Mora. Ludovico Sforza był pierwszym synem Francesca Sforzy narodzonym po objęciu przezeń godności książęcej. Ponadto Mediolan po śmierci Filippa Marii Viscontiego stał się lennem cesarskim, dlatego też cesarz rościł sobie prawo do nadawania go podług własnej woli ${ }^{15}$. Mimo tej manifestacji zwierzchności cesarskiej Maksymilian nalegał, by nadanie to pozostało w tajemnicy aż do chwili, gdy nadejdzie odpowiedni czas, by je ujawnić.

Pamiętajmy jednak, że - jak pisał Jacob Burckhardt - „podstawa ich władzy jest i pozostaje nielegalna i ciązy na niej przekleństwo nie dające się zażegnać. Nie zmieniają tego cesarskie zatwierdzenia i inwestytury, bo lud się $z$ tym nie liczy, że jego władcy gdzieś tam w dalekich krajach lub u przejezdnego cudzoziemca kupili sobie kawałek pergaminu. Gdyby cesarze byli coś warci, nie byliby tyranów dopuścili do władzy - rozumowali prości ludzie. Od wyprawy Karola IV na Rzym cesarze sankcjonowali tylko stan bezprawia, jaki powstał bez ich woli, nie mogac mu jednak udzielić najmniejszej gwarancji poza dokumentem urzędowym"16.

Uzyskawszy taka legitymizację swych działań, której skuteczność była co najmniej problematyczna nawet dla niego samego, Ludovico szybko rozprawił się z przeciwnikami, którzy mogliby rywalizować $z$ nim o władzę $\mathrm{w}$ księstwie lub się jej przeciwstawiać: braćmi, kanclerzem Francesco (Cicco) Simonettą, który zdecydowany był bronić praw małego księcia ${ }^{17}$, oraz księżna-matką i jej kochankiem.

Kiedy na świat przyszedł syn prawowitej pary książęcej Mediolanu (1492), Gian Galeazza i Izabeli d'Aragona, odprawiono jedynie bardzo skromna ceremonię, tak że powszechnie podejrzewano nawet ich potomka o ułomność. Zupełnie innego przyjęcia doznał

15 Więcej na ten temat por. J. Black, Absolutism in Renaissance Milan. Plenitude of Power under the Visconti and the Sforza 1329-1535, Oxford 2009.

16 J. Burckhardt, Kultura odrodzenia we Włoszech. Próba ujęcia, wstęp M. Brahmer, Warszawa 1991, s. 31.

17 Kanclerz zostal stracony 30 X 1480 r. P. Colussi, Cicco Simonetta, capro espiatorio di Ludovico il Moro, [w:] Storia di Milano, vol. VII, Milano 1957, http://www.storiadimilano.it/Personaggi/Milanesi\%20illustri/CiccoSimonetta.htm (dostęp: 16 IX 2019). 
syn Ludovica i jego żony, Beatrycze d'Este. Przygotowania rozpoczęto już w pierwszych dniach stycznia 1493. Zamek został bogato przyozdobiony. „Komnatę, w której miało nastapić radosne wydarzenie, wyposażono w nowe łoże i wystawne sprzęty [...]. 25 stycznia, w dniu, kiedy Beatrice wydała na świat syna, Mediolan ogarną entuzjazm nie tyle nawet $z$ powodu doniosłego wydarzenia, ile na widok żywności i napojów, które Ludovico kazał rozdzielić wśród ludności. W godzinę po narodzinach małego Sforzy w dwustu mediolańskich kościołach rozbrzmiały dzwony"18, a na ulice miasta wyległy tłumy jego mieszkańców. Wkrótce potem heroldowie rozgłosili, że Ludovico postanowił ułaskawić wszystkich skazanych za długi i wypłacić jałmużnę kościołom. Pod wieczór z katedry wyruszyła uroczysta procesja dziękczynna, w której udział wzięli kler i przedstawiciele różnych zakonów.

Dziecko otrzymało imiona Ercole (był to ukłon złożony ojcu Beatrice, księciu Ferrary) Maksymilian (to podkreślać miało sympatię Sforzów dla cesarstwa). Ludovico zarządził, aby uroczystości urodzinowe trwały przez miesiąc. Nie mogło być watpliwości, że oto narodził się prawdziwy następca tronu.

Po śmierci bratanka, Gian Galeazza, nastąpił ostatni akt przejęcia władzy przez Ludovica. Moro pośpieszył do Mediolanu, gdzie - zgromadziwszy w Castello najznamienitszych obywateli miasta - zaproponował, by księciem ogłoszono synka zmarłego, Francesco. W tym jednak momencie skarbnik, Antonio Landriano (co w oczywisty sposób było $z$ góry ukartowane), zaprotestował przeciwko elekcji księcia-dziecka w tak trudnym okresie (inwazja francuska). Wnosząc konstruktywne wotum, zaproponował jednocześnie, by Ludovico, który tak długo już przecież piastował książęce obowiązi, przyją także i tytuł. Baldassare Pusterla, Andrea Cagnola i inni przyjaciele Ludovica przyklasnęli propozycji Landriano, czemu nikt nie ośmielił się zaprotestować. Bez dalszej zwłoki zatem Ludovico ogłoszony został księciem. Dokonał się zamach stanu. Współcześni nie mieli wątpliwości, że Ludovico był uzurpatorem, nie budziło to jednak na innych dworach większego oburzenia.

Zdobyta władzę należało jednak uprawomocnić. Wszyscy książęta-kondotierzy, którzy zdobywali władzę we włoskich państewkach, dążyli do legitymizacji swej pozycji, osiagniętej bardziej lewem niż prawem, niemającej ugruntowania ani dynastycznego,

${ }^{18}$ A. Perria, op. cit., s. 165. 
ani prawnego, ani też demokratycznego ${ }^{19}$. Jedna $z$ najskuteczniejszych dróg wiodacych do zalegalizowania władzy zdobytej $\mathrm{w}$ ten sposób był mecenat kulturalny i artystyczny, fundowanie dzieł sztuki, a przede wszystkim utrzymywanie literatów, poetów i historiografów piszących pochlebnie o nowych książętach, tworzących legendy swych mecenasów i dzięki temu kładacych podwaliny pod uprawomocnienie ich władzy. Tą droga nowi książęta wchodzili do tradycji, budowali swój pozytywny wizerunek i zyskiwali uznanie własnych rządów. Co istotne, podobne próby legitymizacji władzy za pomoca sztuki oraz dzieł humanistycznej historiografii podejmowali także inni współcześni książęta-nuworysze, których władza nie miała solidnego umocowania: nie tylko Wawrzyniec Wspaniały, lecz także papież Sykstus IV ${ }^{20}$, królowie Maciej Korwin czy Jerzy z Podiebradów. Problem ten dotyczył wszystkich przedstawicieli dynastii Sforzów. Jeżeli jednak nawet zjawisko to umożliwiło niebywały rozkwit kulturalny i zapoczątkowanie jednego z największych w dziejach kultury i sztuki przełomu, było tragedia Włoch, że przyszło im za to zapłacić własną niepodległością.

Ludovica nazywano „Peryklesem Mediolanu”. Był on protektorem m.in. Leonarda da Vinci, głównie jednak jako inżyniera, nie artysty. Najlepszą część życia spędził u boku Ludovica w Mediolanie Donato Bramante, spełniając funkcje inżyniera, budowniczego, a $\mathrm{w}$ razie potrzeby także malarza.

W sferze architektury Ludovico odziedziczył po swoich poprzednikach ogromne bogactwo ufundowanych przez nich budowli. Jego główną zasługa na tym polu było upiększanie i powiększanie istniejacych fundacji, zwłaszcza twierdzy w Mediolanie i Certosa di Pavia. Mediolańskie kościoły Santa Maria presso San Celso (il. 1) i Santa Maria presso San Satiro (il. 2), a także Santa Maria delle Grazie (il. 3; w refektarzu tego klasztoru znajduje się słynne malowidło Leonarda, przedstawiające Ostatnią Wieczerzę, powstałe na

${ }^{19}$ M. We ber, Typy władzy prawomocnej, [w:] Twórcy naukowych podstaw organizacji. Wybór pism, red. J. Kurnal, Warszawa 1972, s. 322. Omówienia koncepcji władzy Maxa Webera podją się Marian Orzechowski w monografii Polityka, władza, panowanie w teorii Maxa Webera, Warszawa 1984, por. zwłaszcza rozdział Legitymowanie polityki. Kultura polityczna. Etyka polityczna, s. 325-354. Książka ta jednak zniechęcać może dzisiejszego czytelnika ciągłymi odniesieniami do poglądów Karola Marksa, Fryderyka Engelsa i Włodzimierza I. Lenina. Por. też W. Sokół, Legitymizacja systemów politycznych, Lublin 1997.

${ }^{20}$ Nota bene pochodzacy z Ligurii, pozostajacej pod protektoratem Sforzów i z nimi skoligacony. 


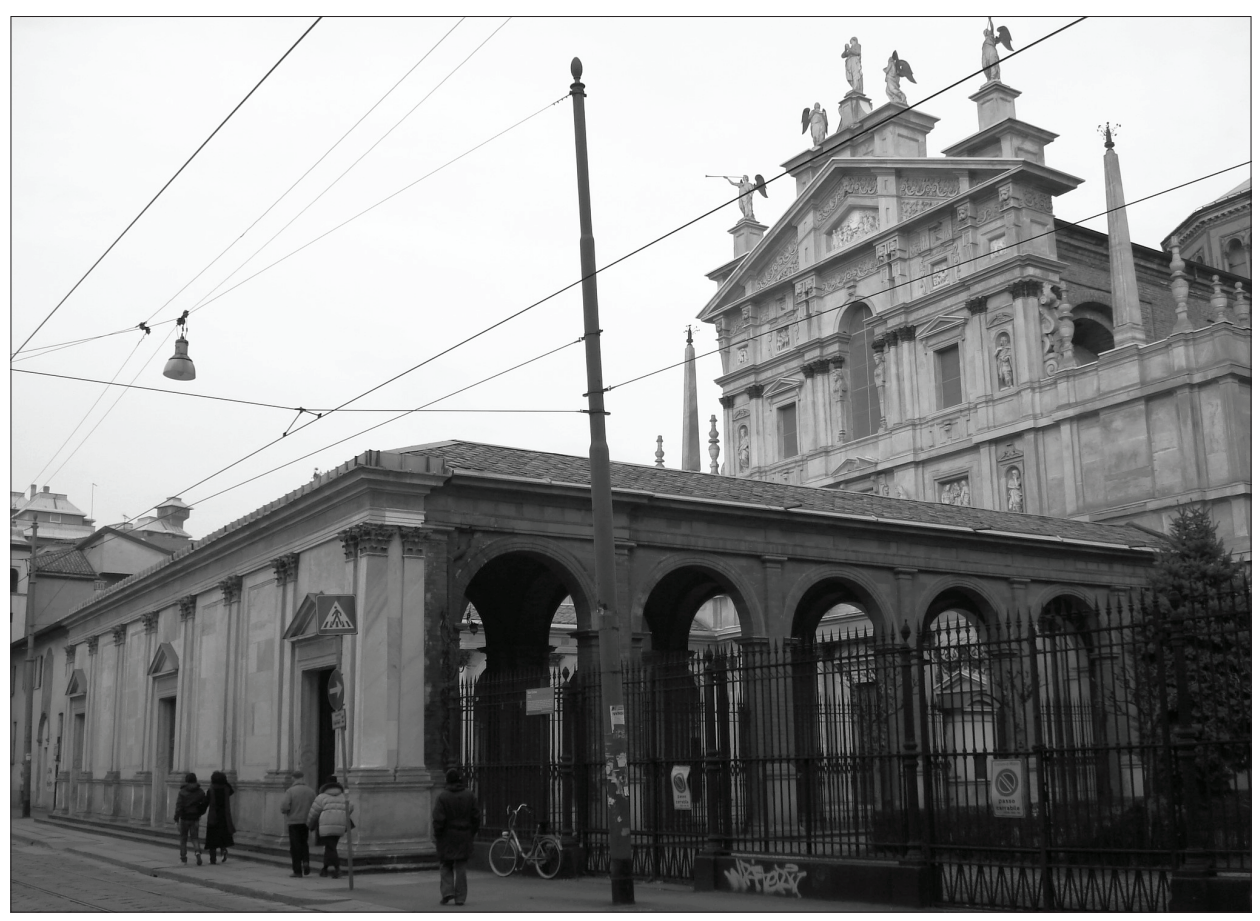

1. Santa Maria presso San Celso. Źródło: Wikimedia Commons

zamówienie Ludovica) i basilica di Sant'Ambrogio (tutaj pracował Donato Bramante) ukończone lub przebudowane zostały za jego panowania. W kościele Santa Maria delle Grazie Ludovico planował wzniesienie mauzoleum rodziny Sforzów ${ }^{21}$ (ostatecznie Ludovico oraz Beatrice d'Este spoczęli w Certosa di Pavia, il. 4-5). Około roku 1490 zdecydował się wznieść katedrę w Pawii (dla której wzorem miała być światynia Hagia Sophia) na miejscu dawnej bazyliki, która szybko popadała w ruinę. Dlatego też Leonardo da Vinci wraz $z$ sieneńskim architektem zostali tam wysłani, by wykonać projekty nowej budowli ${ }^{22}$.

${ }^{21}$ Program artystyczny tej dominikańskiej świątyni jest ściśle podporządkowany celom dynastycznym Sforzów. Por. F. Zölln er, Leonardo da Vinci 1452-1519. Dzieła wszystkie, Köln 2006, s. 136, 230-232.

22 A. Cole, Virtue and Magnificence. Art of the Italian Renaissance Courts, London 1995, s. 93-117, rozdzial Local Tradition and Imported Expertise: Milan and Pavia under Ludovico 'il Moro'; S. Lang, Leonardo's Architectural Designs and the Sforza Mausoleum, „Journal of the Warburg and Courtauld Institutes” 1968, No. 31, s. 218-233. 


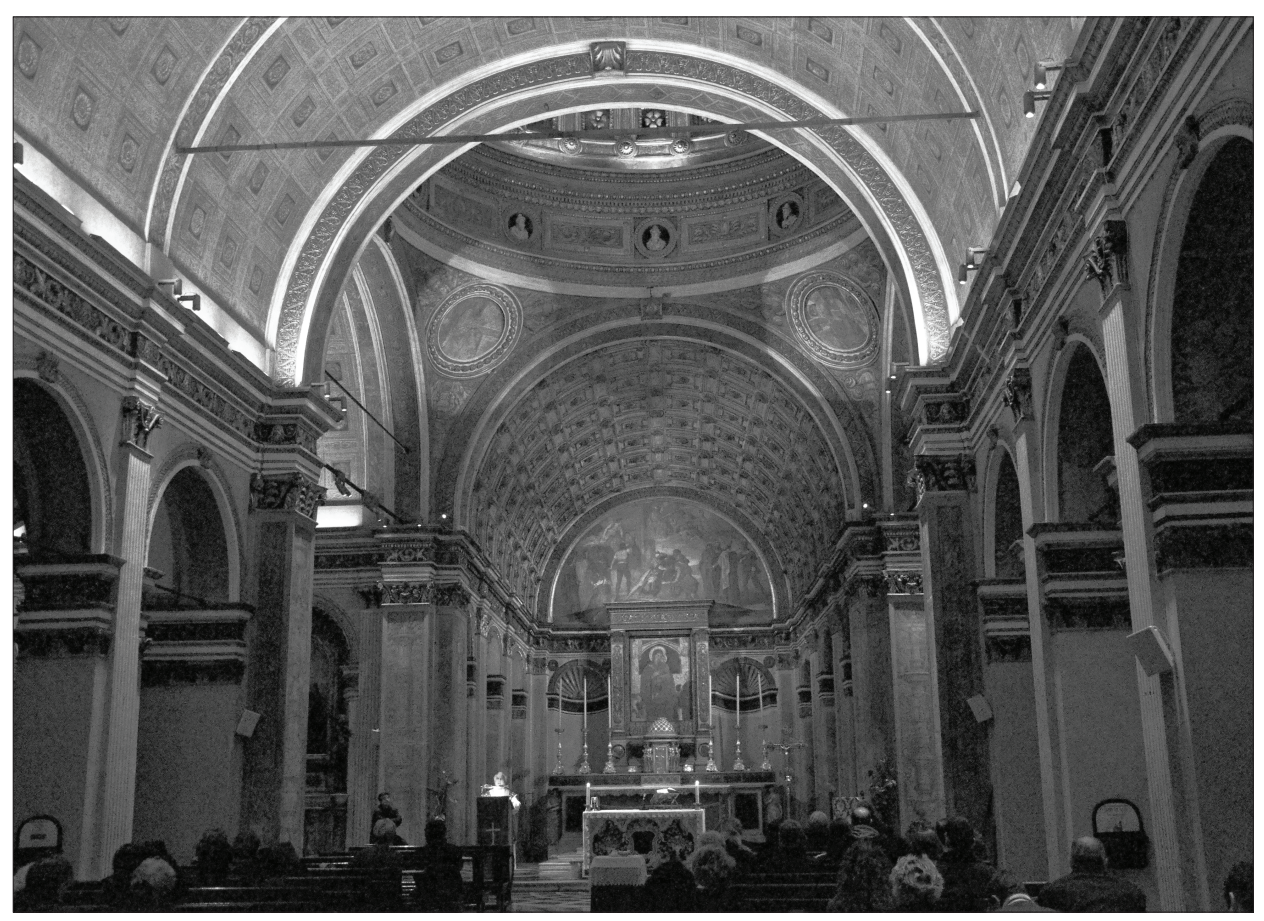

2. Santa Maria presso San Satiro. Źródło: Wikimedia Commons

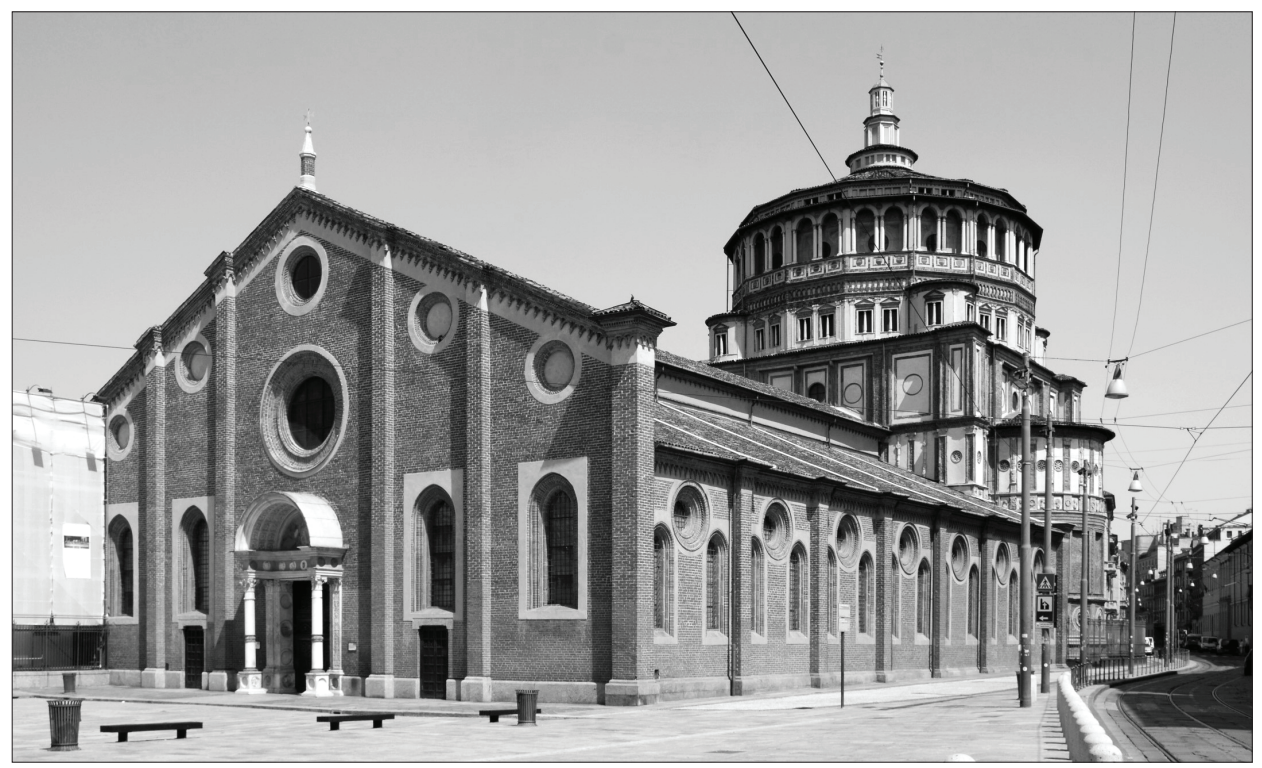

3. Santa Maria delle Grazie. Źródło: Wikimedia Commons 

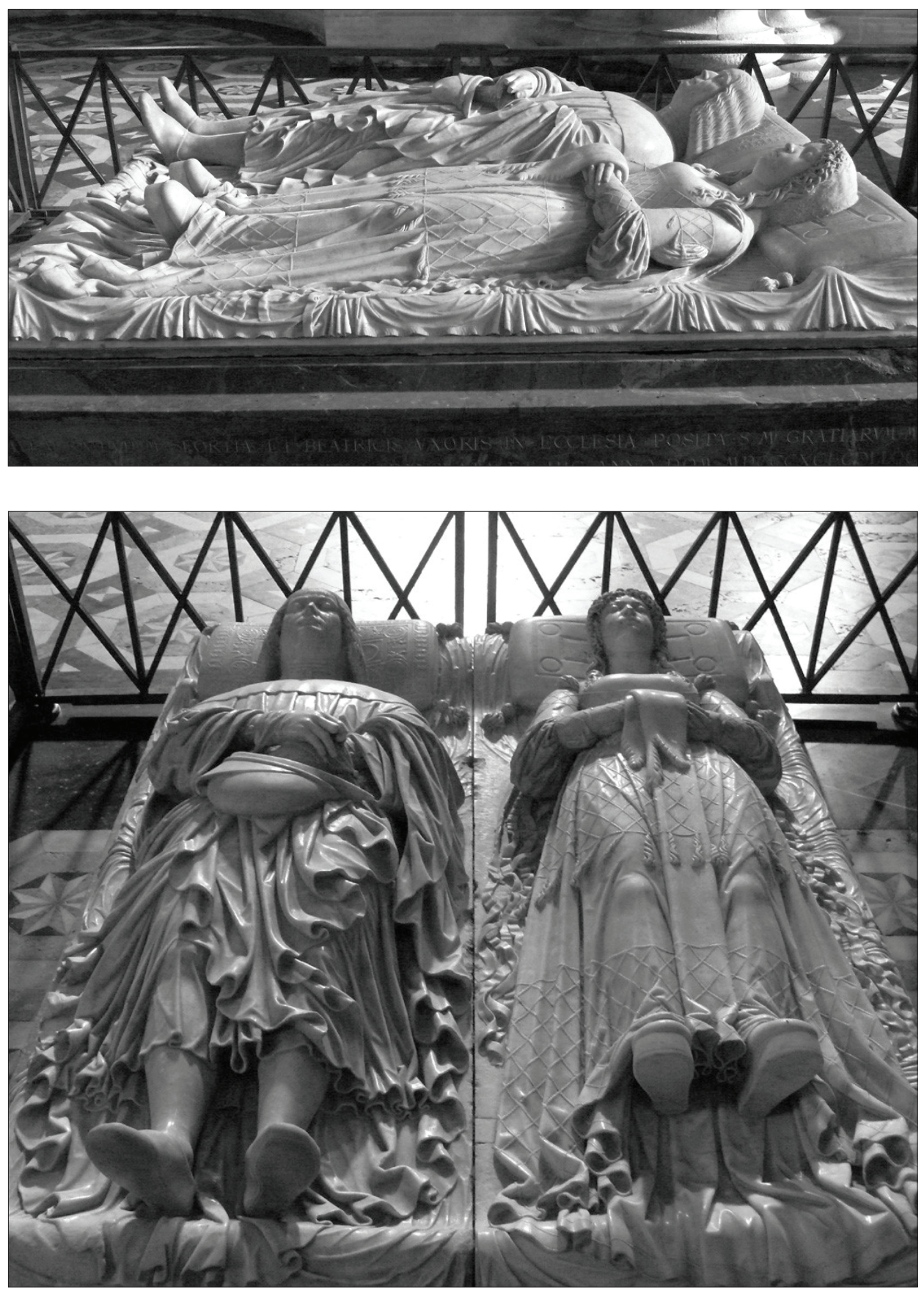

4-5. Nagrobki Ludovica il Moro i Beatrice d'Este w Certosa di Pavia Źródło: Wikimedia Commons 
Dojście Ludovica do władzy stworzyło dogodne warunki do rozkwitu sztuk pięknych w stolicy Lombardii. Przy wszystkich jego wadach zamiłowanie do splendoru i ambicja w połaczeniu ze smakiem artystycznym czyniły go wybornym mecenasem. Pod jego rządami dwór w Mediolanie stał się rodzajem akademii. Zbierali się tam uczeni $z$ różnych części Italii, różnego pochodzenia i różnych talentów. Byli wśród nich Grecy, Wenecjanie i Florentczycy, sekretarze, prawnicy i profesorowie, a wszyscy spotykali się na równych prawach, wyznaczanych przez książęcy patronat i zjednoczeni wspólnym im wszystkim entuzjazmem do literatury. Stosunkowo niewielu dworzan było rodowitymi Mediolańczykami.

Trzecią część dochodów księstwa Moro wydawał na klejnoty i arrasy oraz na pensje dla malarzy i poetów. Pod jego rządami Mediolan stał się stolica dobrego smaku i sztuk pięknych, przystanią dla każdego, kto kochał się w okazałości i przepychu. Jak pisał Myron Gilmore, kiedy Ludovico odebrał władzę legalnemu spadkobiercy, utrzymanie wspaniałego dworu stało się w najwyższym stopniu sprawa polityczną ${ }^{23}$.

Autorka jednej $z$ biografii Leonarda, Antonina Vallentin, podaje kilka interesujacych nas szczegółów: „Da Vinci [...] rysował różne alegoryczne obrazki i usiłował zwalczać plotki krążące dookoła ambicji i egoizmu Lodovica. W bardzo wielu szkicach i rysunkach, po których pozostały jedynie okruchy notatek, Leonardo uprawiał skuteczna propagandę na rzecz regenta Mediolanu. I tak np. narysował Zazdrość wyciagająca do il Moro okulary - symbol jasności wzroku, podczas gdy symbolicznie czarna Sprawiedliwość świadczyła na korzyść regenta (zbiory Bonnata w Bayonne). Innym razem narysował koguta (gallo - symbol Giana Galeazza) ze stadem wilków dookoła, podczas gdy strwożona gołębica (godło Bony Sabaudzkiej) trzepotała skrzydłami, a Przezorność śpieszyła na pomoc $z$ gałęzia żarnowca, ulubionym symbolem Lodovica, $\mathrm{w}$ dłoni (Christ Church College, Oxford). Jakkolwiek jednak Leonardo nie szczędził trudu, by bronić oczernianej cnoty wcielanej w gronostaja brnącego po błocie, by malować Giana Galeazza szukającego schronienia w fałdach płaszcza il Moro, by przedstawić Ludovica jako Fortunę wypędzającą ubóstwo, wydaje się, że w usiłowaniach tych był mniej szczęśliwszy niż inni, zawodowi pochlebcy u dworu. Artysta stale widział, jak na jego drodze stają różne nędzne istoty

${ }^{23}$ M.P. Gilm ore, The World of Humanism 1453-1517, New York 1952, s. 154. 
mające większą wprawę w graniu na strunach słabostek i próżności księcia, mogące trzymać go w swojej mocy tak, jak to potrafi służalczy podwładny w stosunku do nieufnego władcy, do którego zawsze znajdzie dostęp każdy powiew pochlebstwa"24. Sądzę, że nie ulega watpliwości, że te zjawiska artystyczne należy omawiać w kontekście konieczności legitymizacji władzy, przed jaką staną niedoszły mecenas Leonarda.

Po bitwie pod Fornovo, po zakończeniu pierwszej francuskiej inwazji w Italii (1494) Ludovico znalazł się u szczytu potęgi. „Mniej więcej w tym czasie rozpowszechnił on we Włoszech alegoryczny wizerunek przedstawiajacy go jako murzyna $z$ miotłą. Liczac na krótka pamięć swoich ziomków Ludovico przedstawiał siebie jako oswobodziciela kraju z rak obcych barbarzyńców"25, podczas gdy przecież to on właśnie w głównej mierze sprowadził Francuzów do Włoch, nakłaniając ich do zbrojnej interwencji.

Ważnym zagadnieniem jest spożytkowanie na nowo czy też przeprogramowanie przez nowego władcę dzieł historiograficznych. Ciekawym tego przykładem jest wykorzystanie tekstu Commentarii rerum gestarum Francisci Sfortiae Giovanniego Simonetty ${ }^{26}$ (il. 6), najwybitniejszego $z$ humanistycznych historyków Mediolanu drugiej połowy XV w. Skomponowane przez Simonettę dzieło miało za zadanie legitymizację władzy Francesca.

By zrealizować to zadanie, dziejopis przyjął szczególny sposób pracy, wzorując się na Komentarzach Juliusza Cezara. Wizerunek bohatera zbudowany został na jego zaletach wewnętrznych, bez odwoływania się do jakichkolwiek czynników zewnętrznych i bez jakichkolwiek, najdrobniejszych choćby, aluzji do historii jego rodziny. Kondotier przedstawiony został jako jednostka bez przeszłości,

${ }^{24}$ A. Vallentin, Leonardo da Vinci, Warszawa 1951, s. 146. Por. też F. Zö11ner, op. cit., s. 94.

${ }^{25}$ A. Vallentin, op. cit., s. 179.

${ }^{26}$ Był on sekretarzem Francesca Sforzy, młodszym bratem Cicco. Dzięki niemu najpierw awansował w hierarchii kancelaryjnej, a następnie, po jego upadku i egzekucji, spotkała go niełaska nowego władcy, uwięzienie i wygnanie. Por. Johannis Simonetae Rerum gestarum Francisci Sfortiae Mediolanensium Ducis Commentarii, a cura di G. Sorano, Bologna 1932, Rerum Italicarum Scriptores XXI, 2; G. Ianziti, A Humanist Historian and His Documents: Giovanni Simonetta, Secretary to the Sforzas, "Renaissance Quarterly” 1981, vol. XXXIV, No. 4, s. 491-516; id e m, The First Edition of Giovanni Simonetta's 'De Rebus Gestis Francisci Sfortiae Commentarii'. Questions of Chronology and Interpretation, „Bibliothèque d'Humanisme et Renaissance" 1982, vol. XLIV, No. 1, s. 137-147. 


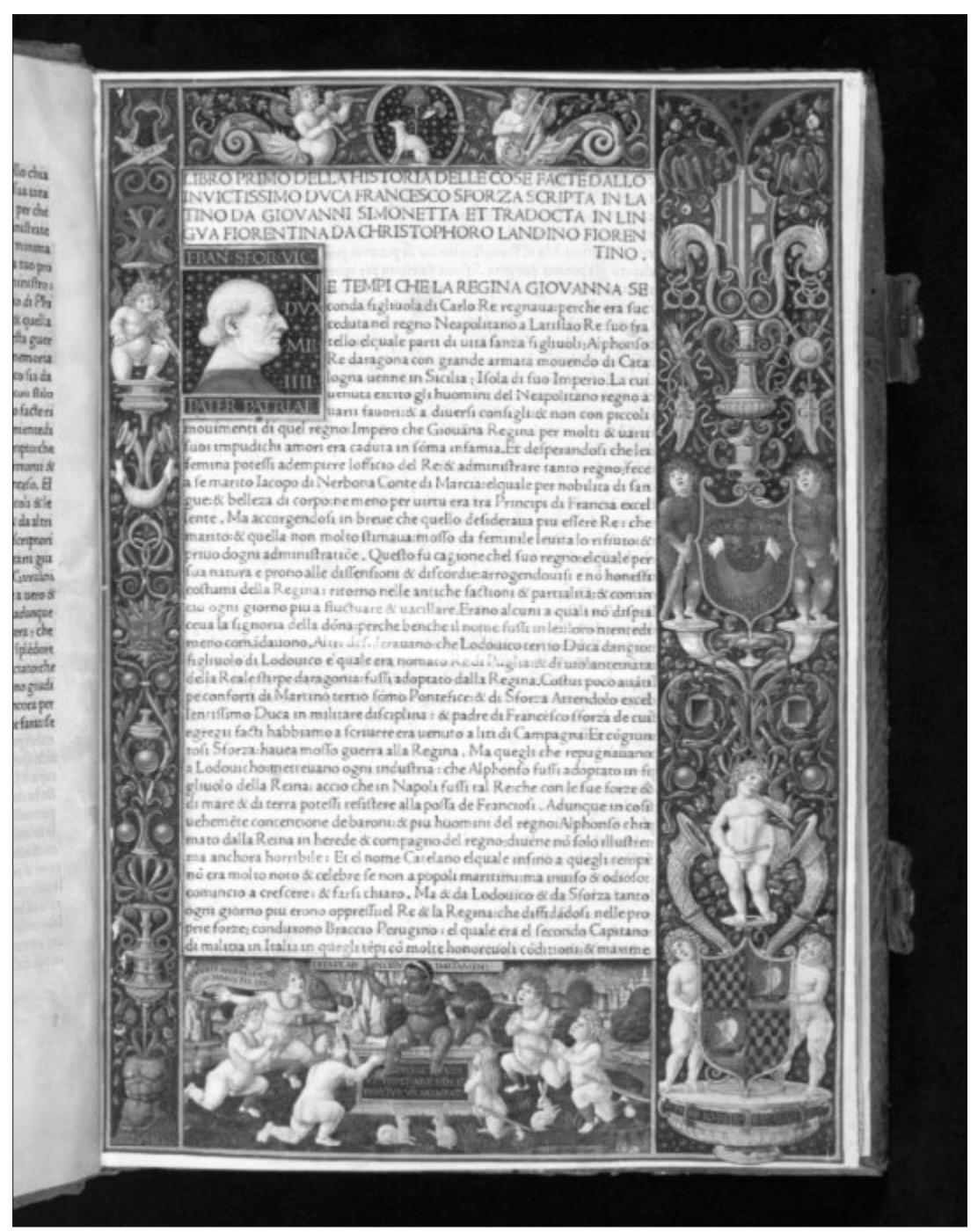

6. Giovanni Simonetta, Commentarii rerum gestarum Francisci Sfortiae, 1490, egzemplarz warszawski. Źr ódło: Polona, https:/ / polona.pl/item/1520897/14/

bez rodziny, bez rodowodu, bez pretensji dynastycznych, a wszystko to świadczyć miało o jego osobistej wielkości i niezwykłych zdolnościach, które wystarczyć miały, by uczynić zeń władcę.

Commentarii stały się ważną częścią programu kulturalnego Ludovica Sforzy. Rękopis wpadł w jego ręce po tym, jak obaj bracia Simonetta popadli w niełaskę, a ich majątek został skonfiskowany. Dzieło wzbudziło ogromne zainteresowanie księcia, który naj- 
prawdopodobniej od razu zorientował się, że historia ojca może być potencjalnie użyteczna do wzmocnienia jego własnej pozycji. Jeszcze za jego życia dzieło doczekało się czterech wydań. Pierwsze przygotowane zostało przez poetę dworskiego Francesca Puteolana w latach 1481-1483, w ciagu dwu następnych lat ukazało się wykonane przez Cristofora Landina tłumaczenie na język włoski (toskański), w roku 1486 druga edycja łacińska, wreszcie do roku 1490 przygotowano i opublikowano poprawiona wersję tłumaczenia Landina. Uwaga, jaka poświęcano dziełu Simonetty, ściśle wiązała się $z$ prowadzona przez Ludovica kampania propagandowa, majaca na celu umocnienie jego władzy.

Przede wszystkim Commentarii miały usprawiedliwiać objęcie przez niego opieki nad bratankiem. We wstępie dołączonym przez F. Puteolana do pierwszego wydania wydarzenie to przedstawione zostało jako realizacja woli samego Galeazzo Marii. W dalszej perspektywie Ludovico zamierzał uczynić z tej księgi narzędzie, które pomóc miało mu w przygotowaniu terenu dla stopniowej uzurpacji władzy odbieranej prawowitemu spadkobiercy. Jako kronika czynów Francesca Sforzy w sposób pośredni służyć mogła do wpajania czytelnikom przekonania o wartości jego najstarszego żyjącego syna.

Niemniej jednak koncepcje historiograficzne Ludovica sięgały dalej. Zależało mu bowiem na przedstawieniu historii Mediolanu, a także historii rodu Viscontich, jako tego czynnika, który uosabiał tożsamość miasta. W tej koncepcji zawierała się implicite idea rodu Sforzów jako kontynuatorów Viscontich (przypomnijmy, że matką Ludovica była Bianca Maria Visconti). Nastapiło więc istotne przeprogramowanie pierwotnego tekstu Commentarii. Francesco Sforza przestał być wyizolowanym bytem, niezależnym od całego otoczenia, dokonującym w pojedynkę doniosłych czynów. Jego postać stała się teraz częścią większej całości, o co zadbali historycy na służbie Ludovica.

Swego rodzaju uzupełnieniem pracy Giovanniego Simonetty miało stać się dzieło Giorgio Meruli, wezwanego do Mediolanu w roku 1482 w celu spisania historii rodu Viscontich. Dzięki temu Sforza planował związać swoje imię $z$ rodzina poprzednich władców państwa, by nadać swoim pretensjom do przejęcia władzy argument dynastyczny. Chodziło o przedstawienie go jako prawowitego dziedzica, uprawomocnionego długa tradycją sięgajaca dalekiej przeszłości w historii miasta. 


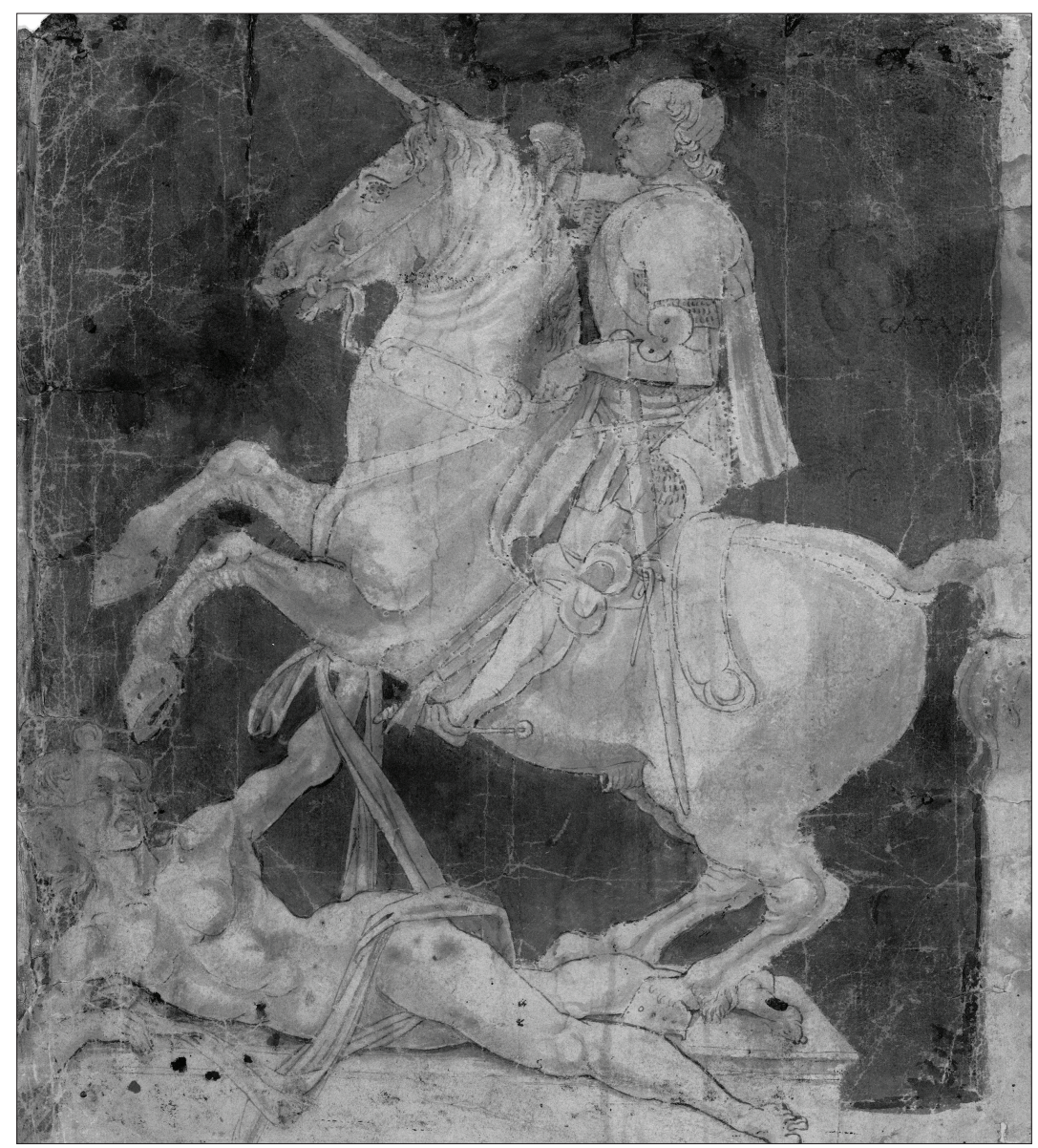

7. Antonio Pollaiuolo, Studium do pomnika konnego Francesca Sforzy Źródło: http://www.metmuseum.org/art/collection/search/459186

Historia Meruli nie ujrzała ostatecznie światła dziennego za życia Ludovica, choć sam mecenas poświęcił temu dziełu wiele uwagi i wysiłku, zależało mu bowiem na stworzeniu kompletnej i dokładnej historii Mediolanu. Pragnał dzieła opisującego historię księstwa i jego poprzedników-przodków. Po śmierci Meruli (zm. 1494) zadanie powierzone zostało Tristanowi Calchi, a wreszcie Bernardinowi Corio. Zachował się ciekawy list z 1497 r., w którym książę polecał biskupom, opatom i świeckim urzędnikom udzielać wszelkiej pomocy Coriowi, który został przezeń wysłany, by „odkrywać wszelkie starożytne pisma dotyczące historii i czynów naszych przodków". Wszyscy lojalni poddani księcia wezwani zostali do 


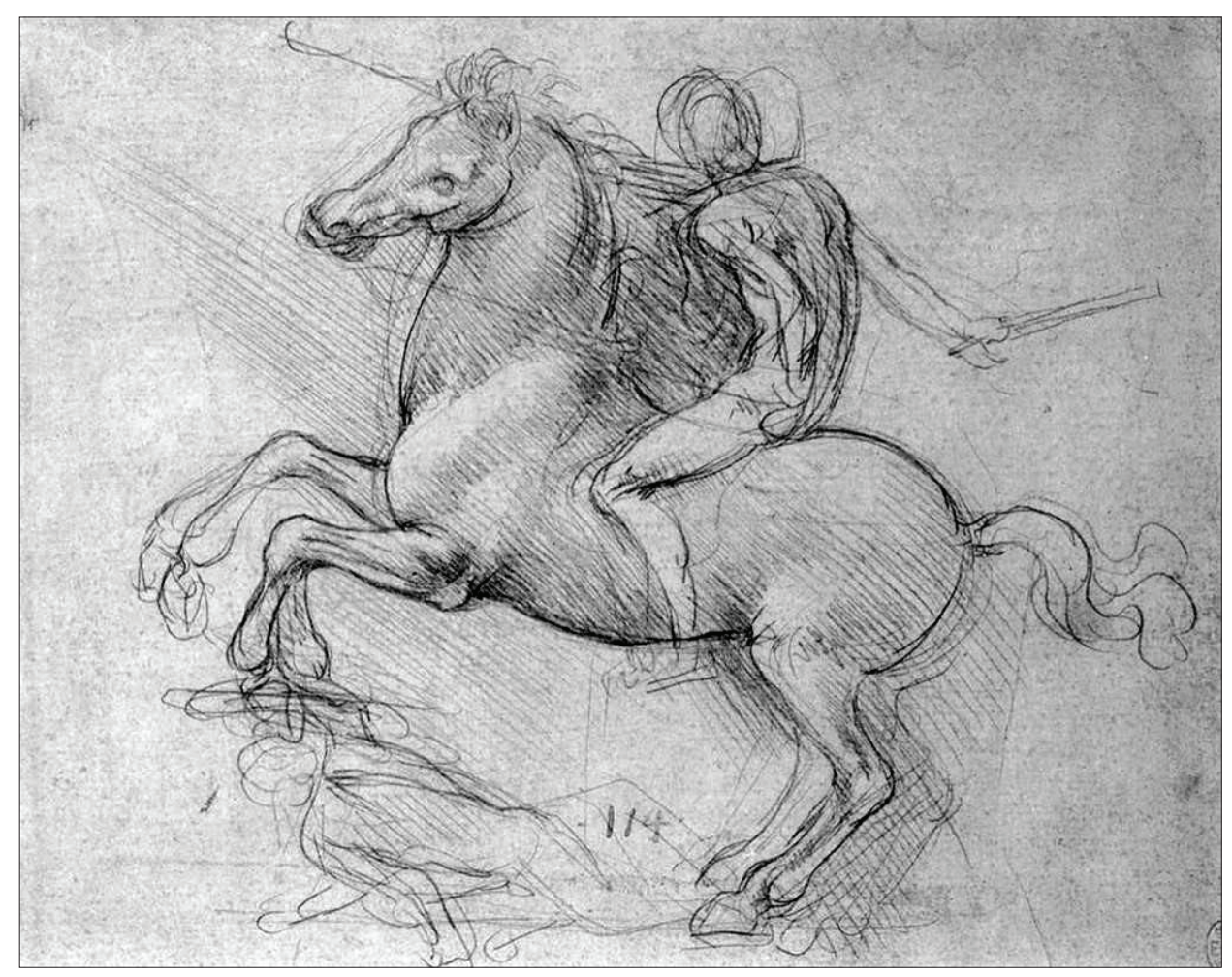

8. Leonardo da Vinci, Studium do pomnika konnego Francesca Sforzy Źródło: Wikiart, http:/ / www.wikiart.org/en/leonardo-da-vinci/a-study-for-an-equestrian-monument

udzielania pomocy historykowi, bez ograniczeń otwierając przed nim archiwa i biblioteki i udzielając mu wszelkiej pomocy i ułatwień w czytaniu i kopiowaniu dokumentów, nawet jeśliby miało to oznaczać wypożyczanie mu manuskryptów do jego mieszkania, a w razie potrzeby choćby do Mediolanu. Podobna rolę odgrywać miała Chronica Bossiana, napisana przez mediolańskiego patrycjusza Donata Bossiego i opublikowana drukiem w $1492 \mathrm{r.}^{27}$

Realizacja tego samego projektu w dziedzinie sztuk plastycznych miał być projektowany przez Leonarda da Vinci wielki posag konny Francesca Sforzy. „Odlany z brazu pomnik, o wiele większy od wymiarów naturalnych, miał w zamierzeniu Ludovica Sforzy upamiętniać sukcesy militarne jego ojca, a blask chwały miał

${ }_{27}$ G. Ianziti, Humanistic Historiography under the Sforzas. Politics and Propaganda in Fifteenth-century Milan, Oxford 1988, s. 232-235. 
opromieniać przy okazji jego własne dokonania"28 (i1. 7: Antonio Pollaiuolo, Studium do pomnika konnego Francesca Sforzy; il. 8: Leonardo da Vinci, Studium do pomnika konnego Francesca Sforzy).

Ludovico był ostatnim suwerennym władca Mediolanu $z$ dynastii Sforzów. Na planach dynastycznych zemściły się jego własne błędy. To on ściagnął do Italii Francuzów, którzy uczynili z niego dożywotniego więźnia, a $z$ jego księstwa terytorium zależne. Próba legitymizacji władzy despotycznej, choć podjęta $z$ wielkim rozmachem na wielu polach, nie powiodła się, choć istotne skądinąd dążenia republikańskie poddanych odegrały w upadku księcia rolę znikomą, o ile w ogóle jakąkolwiek.

\section{Bibliografia}

\section{ŹRÓDEA DRUKOWANE}

Guiccardini F., The History of Italy, Princeton 1984.

Johannis Simonetae Rerum gestarum Francisci Sfortiae Mediolanensium Ducis Commentarii, a cura di Giovanni Sorano, Bologna 1932, Rerum Italicarum Scriptores XXI, 2.

Material for a History of Pope Alexander VI, his Relatives, and his Time, ed. P. De Roo, vol. II (Roderic de Borgia from the Cradle to the Throne), Bruges 1924.

Zöllner F., Leonardo da Vinci 1452-1519. Dzieła wszystkie, Köln 2006.

\section{Opracowania}

Ady C.M., A History of Milan under the Sforza, London 1907.

Azzolini M., The Duke and the Stars. Astrology and Politics in Renaissance Milan, Cambridge-London 2013.

Black J., Absolutism in Renaissance Milan. Plenitude of Power under the Visconti and the Sforza 1329-1535, Oxford 2009.

Burckhardt J., Kultura odrodzenia we Włoszech. Próba ujęcia, wstęp M. Brahmer, Warszawa 1991.

Cole A., Virtue and Magnificence. Art of the Italian Renaissance Courts, London 1995.

Gilmore M.P., The World of Humanism 1453-1517, New York 1952.

Ianziti G., The First Edition of Giovanni Simonetta's 'De Rebus Gestis Francisci Sfortiae Commentarii'. Questions of Chronology and Interpretation, „Bibliothèque d'Humanisme et Renaissance" 1982, vol. XLIV, No. 1, s. 137-147.

Ianziti G., A Humanist Historian and His Documents: Giovanni Simonetta, Secretary to the Sforzas, „Renaissance Quarterly” 1981, vol. XXXIV, No. 4, s. 491-516.

${ }^{28}$ F. Zöllner, op. cit., s. 85 i n. 
Ianziti G., Humanistic Historiography under the Sforzas. Politics and Propaganda in Fifteenth-century Milan, Oxford 1988.

Lang S., Leonardo's Architectural Designs and the Sforza Mausoleum, „Journal of the Warburg and Courtauld Institutes" 1968, No. 31, s. 218-233.

Orzechowski M., Polityka, władza, panowanie w teorii Maxa Webera, Warszawa 1984.

Pellegrini M., Ascanio Maria Sforza: La parabola politica di un cardinale-principe del rinascimento, t. I-II, Roma 2002.

Perria A., Okrutni Sforzowie, Warszawa 1985.

Sokół W., Legitymizacja systemów politycznych, Lublin 1997.

Vallentin A., Leonardo da Vinci, Warszawa 1951.

Weber M., Typy władzy prawomocnej, [w:] Twórcy naukowych podstaw organizacji. Wybór pism, red. J. Kurnal, Warszawa 1972, s. 317-334.

Welch E.S., Galeazzo Maria Sforza and the Castello di Pavia, 1469, „The Art Bulletin" 1989, vol. LXXI, No. 3, s. 352-375.

\section{NetOGRAFiA}

Colussi P., Cicco Simonetta, capro espiatorio di Ludovico il Moro, [w:] Storia di Milano, vol. VII, Milano 1957, http:/ /www.storiadimilano.it/Personaggi/Milanesi\%20illustri/CiccoSimonetta.htm (dostęp: 16 IX 2019).

Piotr TAfiŁowski

\section{Absolutism and legitimacy of power in Milan under the rule of Ludovico Sforza 'Il Moro'}

Thant he paper seeks to present the forms of legitimacy, as well as the means and tools that have been used for this purpose by usurping authority over Milan Ludovico Sforza. The attempts to legitimate the illegally seized power, taken by the Renaissance and early modern rulers, not only by political meanse, but also through cultural and artistic patronage are very important and interesting issues. The first part of the paper discusses the Ludovico's road to take over the principality; in the second part Ludovico's efforts to legalize his illegal power are described.

Keywords: Milan, the Sforzas, legitimacy, art, historiography. 